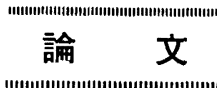

\title{
ほう化処理した鋼の高温酸化についで
}

\author{
渋谷佳 男**.遠藤隆 ${ }^{* *}$
}

\section{High Temperature Oxidation Behavior of Borided Steel}

\section{Yoshio ShIBuYa and Takashi Endo}

Synopsis:

This paper deals with the study of the high temperature oxidation behavior of borided steel and boride at various temperatures and time in air. The low carbon steel was used as the material and the immersion boriding was done with boric acid and potassium borate as sources of boron supply. In the case of heating at high temperature in air, the borided steel was expected to be resistant up to about $700{ }^{\circ} \mathrm{C}$ while $\mathrm{Fe}_{2} \mathrm{~B}$ fully existed. The apparent activation energy $25.1 \mathrm{kcal} / \mathrm{mol}$ was obtained for oxide formation of the boride $\mathrm{Fe}_{2} \mathrm{~B}$ in the temperature range from $700{ }^{\circ} \mathrm{C}$ to $900{ }^{\circ} \mathrm{C}$ in air. Surface boride $\mathrm{Fe}_{2} \mathrm{~B}$ changed as follows with the high temperature oxidation:

$$
\begin{aligned}
\mathrm{Fe}_{2} \mathrm{~B} \longrightarrow & \mathrm{Fe}_{2} \mathrm{~B} \longrightarrow \\
\alpha-\mathrm{Fe} & \mathrm{Fe}_{2} \mathrm{~B} \longrightarrow \underset{\mathrm{Fe}-O x i d e}{ } \longrightarrow \mathrm{Fe}-\mathrm{F} \text {-Oxid } \\
& \mathrm{Fe}-\mathrm{Fxide} \\
& \mathrm{Fe}-\mathrm{B}-\mathrm{Oxide}
\end{aligned}
$$

\section{1. 緒言}

鋼のほう化処理は非常に高い表面硬さを得ることがで き，今後機械部品などに応用が広く，随所に使用される ものと考えられる. 一方, ほう化処理した鋼の高温酸化 については報告が少ないう充, 耐高温酸化性の評価は必 ずしも一致しない，大気中で $850^{\circ} \mathrm{G}^{11}$ ， あるいは $950^{\circ}$ C ${ }^{2}$ における耐酸化性は良好である，という説や耐高温 酸化性はあまり期待できない3)4) という相反する見解が あり，その詳細については不明な点が多い，一方，材料 の機械的性質を改善するために，ホウ化処理後の熱処理 などほう化処理鋼を高温加熱する機会も決して少なくな い.

本研究はほう化処理した鋼の高温酸化挙動を明らかに するために，没せきほう化処理 ${ }^{5}$ した鋼（ほう化層は $\mathrm{Fe}_{2} \mathrm{~B}$ 単相）を $200^{\circ} \mathrm{C} \sim 900^{\circ} \mathrm{C}$ の間で種々の時間大気中加 熱し， ほう化物の走査型電顕（以下電顕上略す）観察， 重量変化，X線回析によるスケールの組成分析，E P M A 分析などにより高温酸化挙動を検討した。

\section{2. 実 験 方 法}

供試材は厚さ $34 \mathrm{~mm}$ の熱間压延後のキャップド鋼か ら切出し試料とした。. 試料寸法は約 $15 \mathrm{~mm} \times 9 \mathrm{~mm} \times 3$ mmである. Table 1 に試料の化学成分を示す. ほう化 処理は Fig. 1 に示すように堅型ニクロム線電気炉を用 い大父中にて行なつた。るつぼはステンレス鋼製るつほ (内径 $\phi 85 \mathrm{~mm} \times 100 \mathrm{~mm}$ ) で試料がるつぼ底部に密着 しないようにニクロム線にて十文字に縛つて処理を行な つた。るつぼはあらかじめ処理温度に加熱，のちに浴を 投入完全に溶融状態になつてから試料をるつぼ直上で30 $\sec$ 程度予熱し，浴中に浸せき， $950^{\circ} \mathrm{G} ， 3 \mathrm{~h}$ および 6 $\mathrm{h}$ 保持した. のちに油冷，試料表面に付着した浴をエメ リーで軽く研摩，除去した。

浴組成は前報6) と同様で $\mathrm{H}_{3} \mathrm{BO}_{3}: 20 \mathrm{wt} \%, \mathrm{~K}_{2} \mathrm{~B}_{4} \mathrm{O}_{7}$. $5 \mathrm{H}_{2} \mathrm{O}: 40 \mathrm{wt} \%, \mathrm{NaF}: 15 \mathrm{wt} \%, \mathrm{~K}_{2} \mathrm{CO}_{3}: 15 \mathrm{wt} \%, \mathrm{Mg}$ 粉末：10wt\% で乳鉢にてよく混合し， $100^{\circ} \mathrm{C}$ で乾燥し てから供した.

高温酸化試験は，模型電気管状炉を用い小型るつほ内 で大気中加熱を行なつた。試料は任意温度で一定時間保 持後，デシケータ中にて放冷し，科量および観察した.

Table 1. Chemical composition of specimen used $(w t \%)$.

\begin{tabular}{l|c|c|c|c|c|c}
\hline $\mathrm{C}$ & $\mathrm{Si}$ & $\mathrm{Mn}$ & $\mathrm{P}$ & $\mathrm{S}$ & $\mathrm{Ni}$ & $\mathrm{Cr}$ \\
\hline 0.07 & 0.50 & 0.33 & 0.009 & 0.011 & 0.024 & 0.016 \\
\hline
\end{tabular}

* 昭和 52 年 5 月 26 日受付 (Received May 26, 1977)

** 静岡県工膵試験場 (Prefectural Industrial Research Institute, Shizuoka, 5-9-3

Komagata-dori Shizuoka 420) 


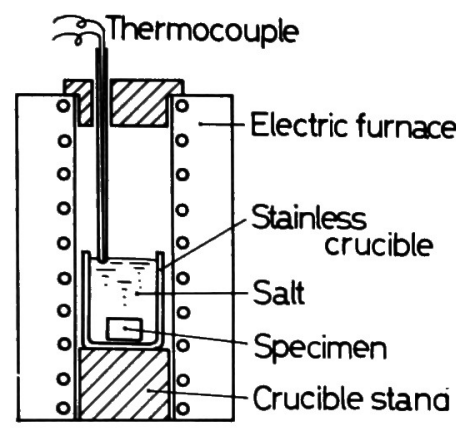

Fig. 1. Experimental apparatus of the boriding.

またほう化物 $\mathrm{Fe}_{2} \mathrm{~B}$ を抽出, 高温加熱し，ほう化物表面 の電顕観察を行なつた. $\mathrm{Fe}_{2} \mathrm{~B}$ の抽出方法は $\mathrm{Fe}_{2} \mathrm{~B}$ が $\mathrm{HCI}$ に対して著しい耐食性6)を示すことを利用し，ほう化処 理鋼の一端を切断, $12 \mathrm{~N}-\mathrm{HCl}$ 中に約 $20 \mathrm{~h}$ 浸せきするこ とにより素地を溶出させ， $\mathrm{Fe}_{2} \mathrm{~B}$ を抽出した，水洗，弱 アルカリ溶液洗浄, ドラィヤー乾燥の後, 各種試験に供 した.

\section{3. 実 験 結 果}

\section{1 高温酸化試料の表面および断面観察}

ほう化処理鋼を $400^{\circ} \mathrm{C}$ から $900^{\circ} \mathrm{C}$ まで $100^{\circ} \mathrm{C}$ 間隔 でおのおの $1,3,8,16 \mathrm{~h}$ 大気中加熱を行ないデシケー タ中にて放冷，後に表面観察を行なつた。 $500^{\circ} \mathrm{C}, 3 \mathrm{~h}$ までは加熱前の試料表面の光沢が認められるが $500^{\circ} \mathrm{C}$ ， $8 \mathrm{~h}$ あるいはそれ以上の温度，および加熱時間では光沢 は認められず薄茶色になつた。 $800^{\circ} \mathrm{C} て ゙ ~ 16 \mathrm{~h}$ ，あるい は $900^{\circ} \mathrm{C}$ など高温になると灰黒色を呈する.

ほう化処理鋼を $800^{\circ} \mathrm{C}, 8 \mathrm{~h}$ 以上加熱した場合，試料 の直角部(各面の接線部)にき裂が認められた.このよう なき裂は， $800^{\circ} \mathrm{C}, 3 \mathrm{~h}$ 加熱までは加熱中，あるいは放冷
中には生じない.しかし $800^{\circ} \mathrm{C}, 8 \mathrm{~h}$ および $16 \mathrm{~h}$ 加熱で は，加熱中にき裂が生じ，デシヶータ内で放冷中にさら にそれが進み，はく㜠も涊以られた．900 $\mathrm{C}$ 加熱では， 加熱中にき裂が生じ放泠中さらに進むがはく離は涊めら れなかつた。

ふくくは， $800^{\circ} \mathrm{C}, 8 \mathrm{~h}, 16 \mathrm{~h}$ および $900^{\circ} \mathrm{C}$ 加熱の場 合, 試料の平面部に認められたが $800^{\circ} \mathrm{C}$ 短時間加熱, あ るいはそれ以下の温度では認められない。

$\mathrm{B}_{4} \mathrm{C}, \mathrm{BCl}_{3}$ 等を主成分で行なう処理7)8) では鋼表面に ほう素濃度の高い FeB 層 (B: 16.4wt\%), その内部に 嶩度の低い $\mathrm{Fe}_{2} \mathrm{~B}$ 層 (B: $\left.8.9 \mathrm{wt} \%\right)$ が生じる. 本報では ほう化層は $\mathrm{FeB}$ は認められず $\mathrm{Fe}_{2} \mathrm{~B}$ 単相である.

Photo. 1 は $950^{\circ} \mathrm{C}, 3 \mathrm{~h}$ ほう化処理後 $700^{\circ} \mathrm{C}$, および $800^{\circ} \mathrm{C}$ で $16 \mathrm{~h}$ 大気中加熱したときの断面組織を示す. $700^{\circ} \mathrm{C}, 16 \mathrm{~h}$ 加熱ではほう化層表面に厚さ約 $28 \mu, 800^{\circ}$ $\mathrm{C} ， 16 \mathrm{~h}$ では約 $92 \mu$ の酸化物スケールが認められた。 ほう化曆表面は侵され，酸化してほう化層の厚さがわず かに減少している. Photo. 2 は $900^{\circ} \mathrm{C}, 16 \mathrm{~h}$ 大気中加 熱したときの断面組織を示す. $700^{\circ} \mathrm{C}, 800^{\circ} \mathrm{C}$ で存在し たほう化層は認められず酸化物スケールが大きく成厓 している.これはほう化物 $\mathrm{Fe}_{2} \mathrm{~B}$ がすべて酸化物に变化 したことを示す. スケールは積層化し多孔質である。 またスケールと素地との界面に大きなき裂が認められ た.

Fig. 2 は種々の温度で高温酸化したほう化処理鋼断面 のE P M A 線分析結果を示す. a， bおよび c は，おの おの $700^{\circ} \mathrm{C}, 800^{\circ} \mathrm{C}$ および $900^{\circ} \mathrm{C} て ゙ ~ 16 \mathrm{~h}$ 大気中加熱 を行なつた、 $\mathrm{a}, \mathrm{b}$ にいては, $\mathrm{Fe}_{2} \mathrm{~B}$ に比較して酸化 物のピークは， $\mathrm{Fe}, \mathrm{B}$ の濃度が低下し， O が高くなつ ている. a , b および c は，おのおの約 $35 \mu, 95 \mu$ お よび $405 \mu$ の厚さの酸化物が認められた。 また a , b は お扰よそ $150 \mu, 120 \mu$ の $\mathrm{Fe}_{2} \mathrm{~B}$ が垫められたがcにつ

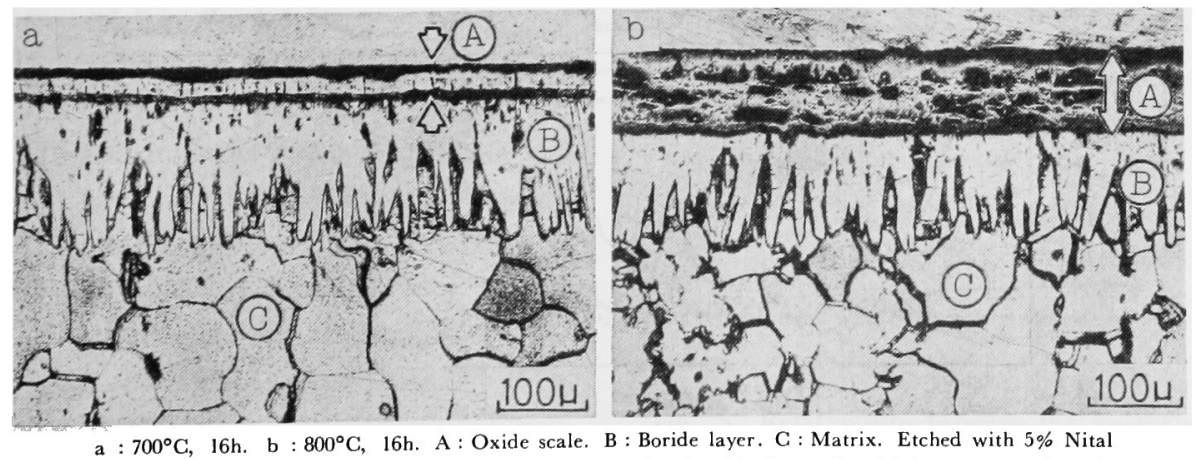

Photo. 1. Cross-sectional optical micrographs of the borided steel which was oxidized at high temperature after being borided at $950^{\circ} \mathrm{C}$ for $3 \mathrm{~h}$. 


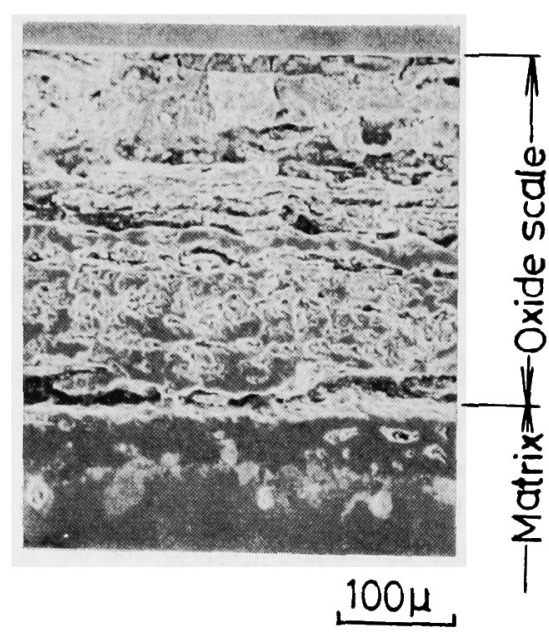

$900^{\circ} \mathrm{C}$, 16h. Etched with $1 \%$ Nital.

Photo. 2. Cross-sectional scanning electron micrograph of the borided steel which was oxidized at high temperature.

いては $\mathrm{Fe}_{2} \mathrm{~B}$ は認められない.これは高温になるにした がい， $\mathrm{Fe}_{2} \mathrm{~B}$ の厚さが減じ酸化物の厚さが増大したこと を示す. $900^{\circ} \mathrm{C}, 16 \mathrm{~h}$ 加熱では $\mathrm{Fe}_{2} \mathrm{~B}$ はすべて酸化物に 変化している.これらは Photo. 2 の観察絬果と同様に 高温で酸化することにより $\mathrm{Fe}_{2} \mathrm{~B}$ が分解， $\mathrm{Fe}$ あるいは $\mathrm{Fe}-\mathrm{B}$ 酸化物に変化したことを示す.

\section{$3 \cdot 2$ 高温酸化したほう化物の電顕観察}

抽出したほう化物の微片を種々の温度, 時間にて大気
中加熱を行ない，素地側からほう化物を観察することに よりほう化物がどの程度, 高温に耐え得るか検討した。

ほう化物のみを加熱した場合，ほう化物がくい状であ るため，大気にられる表面積が大きく，かならずしもほ う化処理鋼の高温酸化挙動と一致しない. しかしほう 化物がどの程度高温に耐え得るかのめやすにはなる. Photo. 3 は, $200^{\circ} \mathrm{C} \sim 600^{\circ} \mathrm{C}$ まで $100^{\circ} \mathrm{C}$ 間隔でおのお の $1 \mathrm{~h}$ 大気中加熱したほう化物 $\mathrm{Fe}_{\mathbf{2}} \mathrm{B}$ の電顕写真であ る、400ㄷ られない.しかし $500^{\circ} \mathrm{C} て ゙ は \mathrm{Fe}_{2} \mathrm{~B}$ の先端がわずかに変 化し， $600^{\circ} \mathrm{C}$ になると先端が丸くなり，高倍率（1000 倍）で観察すると微細な割れが認められた。

Photo. 4 は $700^{\circ} \mathrm{C}$ で種々の時間大気中加熱したほう 化物 $\mathrm{Fe}_{2} \mathrm{~B}$ の電䡩写真である. 抽出したくい状ほう化物 の径はおおよそ $10 \mu \sim 20 \mu$ 程度であり，先端は尖つて いる. $5 \mathrm{~min}$ 加熱では先端がわずかに丸くなる傾向が認 められた，また，くい状ほう化物の表面は微細な凹凸が 生じシワ状を呈した，しかし割れは認められない。これ らは後述の X線回析結果に示すように加熱により $\mathrm{Fe}_{2} \mathrm{~B}$ から $\alpha-\mathrm{Fe}$ が析出, $4 \mathrm{Fe}_{2} \mathrm{~B}+3 \mathrm{O}_{2} \rightarrow 8 \mathrm{Fe}+2 \mathrm{~B}_{2} \mathrm{O}_{3}$ の反応が 生じている. あるいは $\mathrm{Fe}_{x} \mathrm{O}_{y}, \mathrm{Fe}_{X} \mathrm{~B}_{Y} \mathrm{O}_{Z}$, などの化合 物が生じていると考えられる. $10 \mathrm{~min}$ 加熱になるとほう 化物表面のシワ状凹凸がさらに激しくなりほう化物に割 れが生じだ：最初に認められる割れは，くい状ほう化物 にそつた絎方向が多い。をた $30 \mathrm{~min}$ 加熱になる上㓶れ が四方にジグザグ状に進む. $1 \mathrm{~h}$ 加熱ではさらに割れが

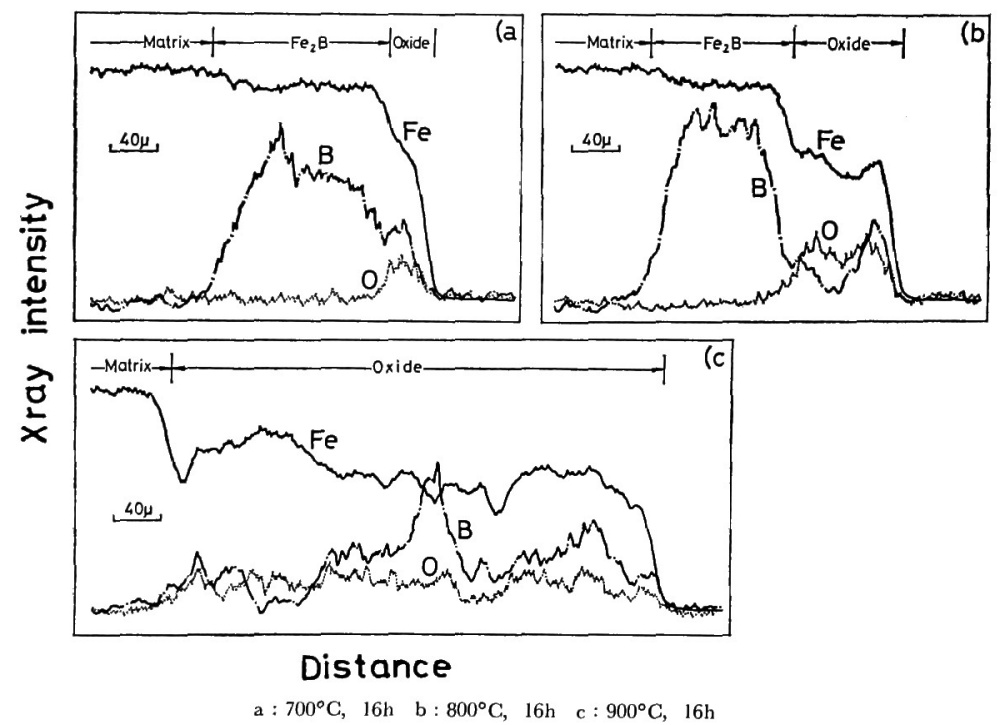

Fig. 2. Line analysis patterns of the EPMA from cross sectional borided steel which was oxidized at high temperature. 

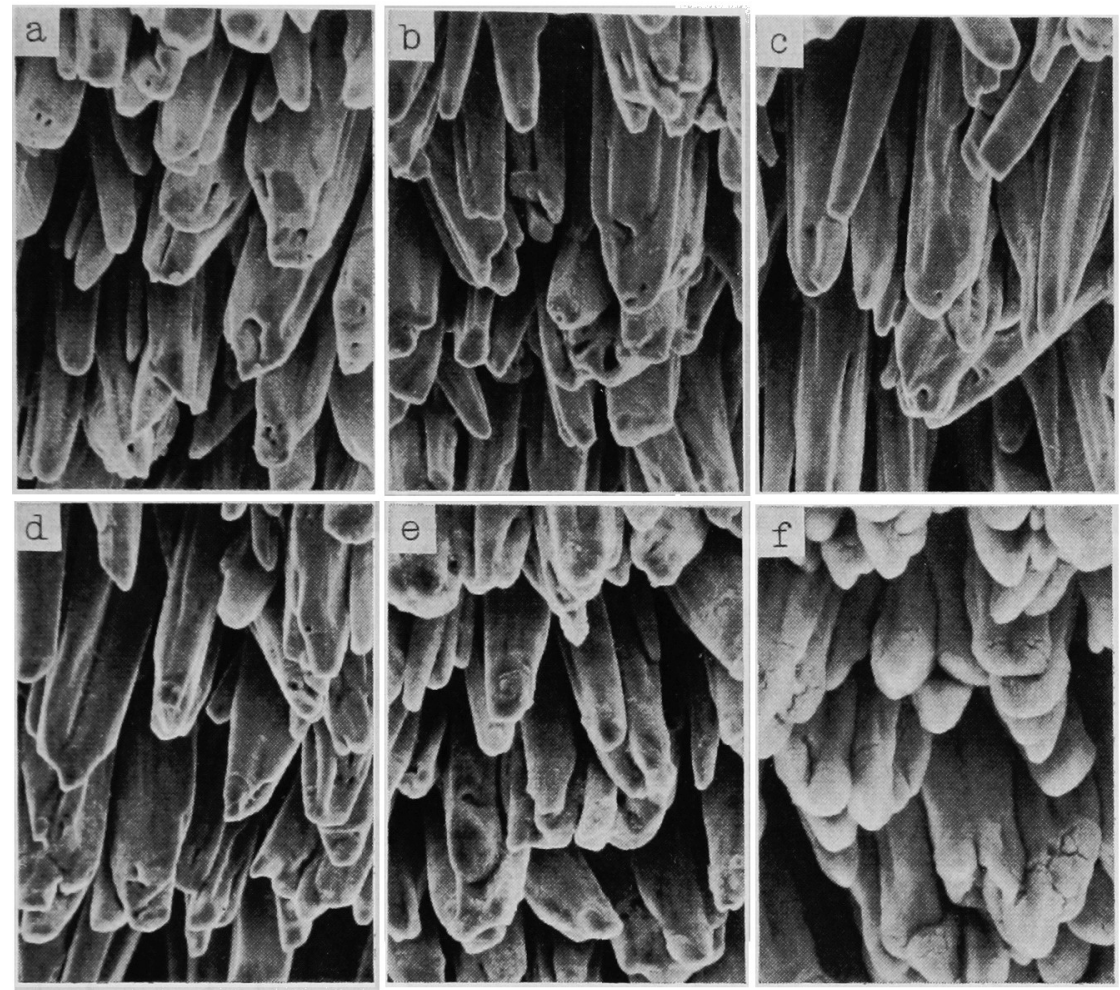

$25 \mu$

a : Before heating. b: $200^{\circ} \mathrm{C}, \quad \mathrm{c}: 300^{\circ} \mathrm{C} . \quad$ d $: 400^{\circ} \mathrm{C}$. e : $500^{\circ} \mathrm{C}$. f : $600^{\circ} \mathrm{C}$. Tilting angle $30^{\circ}$.

Photo. 3. Scanning electron micrographs of the boride $\mathrm{Fe}_{2} \mathrm{~B}$ which was heated in air for $1 \mathrm{~h}$ at various temperatures.

進みくい状ほう化物が崩壊した箇所も認められた。

\section{3 重量增加, 活性化エネルギー}

Fig. 3 はほう化処理銅，および未処理鋼を種々の温 度，時間にて大気中加熱した場合の試料の重量增加を示 す. 加熱は断続加熱で同一試料を用い，各時間ごとにデ シケータ中放冷したのち秤量した。断続加熱は連続加熱 に比べ酸化物スケールのき裂, はく離を促進させ耐酸化 性纪不利に作用する9)といわれている。

図から明らかなようにほう化処理鋼は未処理鋼に比較 乙高温酸化による重量增加は少なく耐酸化性は良好であ る.これは明らかにほう化物が金属の保護被膜として作 用していることを示す. ほう化処理鋼と未処理鋼との重 量增加の比は $3 \mathrm{~h}$ 加熱の場合, おおよそ $700^{\circ} \mathrm{C} て ゙ 1 / 6$, $800^{\circ} \mathrm{C}$ で $1 / 4$ である. また未処理鋼 $800^{\circ} \mathrm{C}, 1 \mathrm{~h}$ と処 理鋼 $900^{\circ} \mathrm{C}, 5 \mathrm{~h}$ 加熱の重量增加量がほぼ等しい.

ほう化処理鋼を大気中加熱し， $\mathrm{Fe}_{2} \mathrm{~B}$ 表面上に生じる 酸化物形成の見かけの活性化エネルギーの概算值を求め た. 一般に酸化皮膜の膜厚が $1000 \AA$ 以上のものは放物 線則に従がうとされている。本実験の範囲でもFig. 3

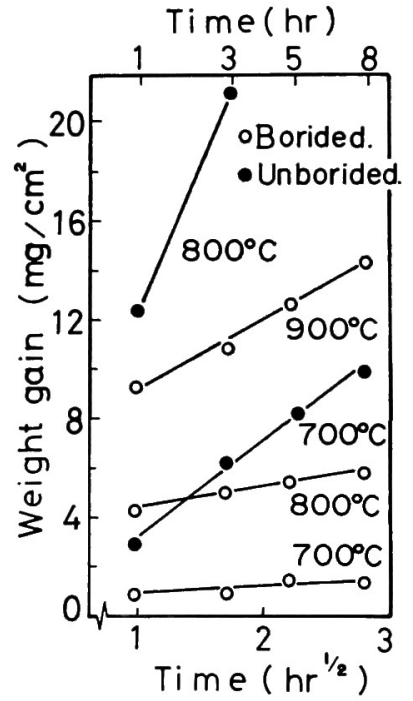

Fig. 3. Relationship between the weight gain of the various specimens and the heated temperature or time. The boriding was made at $950^{\circ} \mathrm{C}$ for $6 \mathrm{~h}$. 

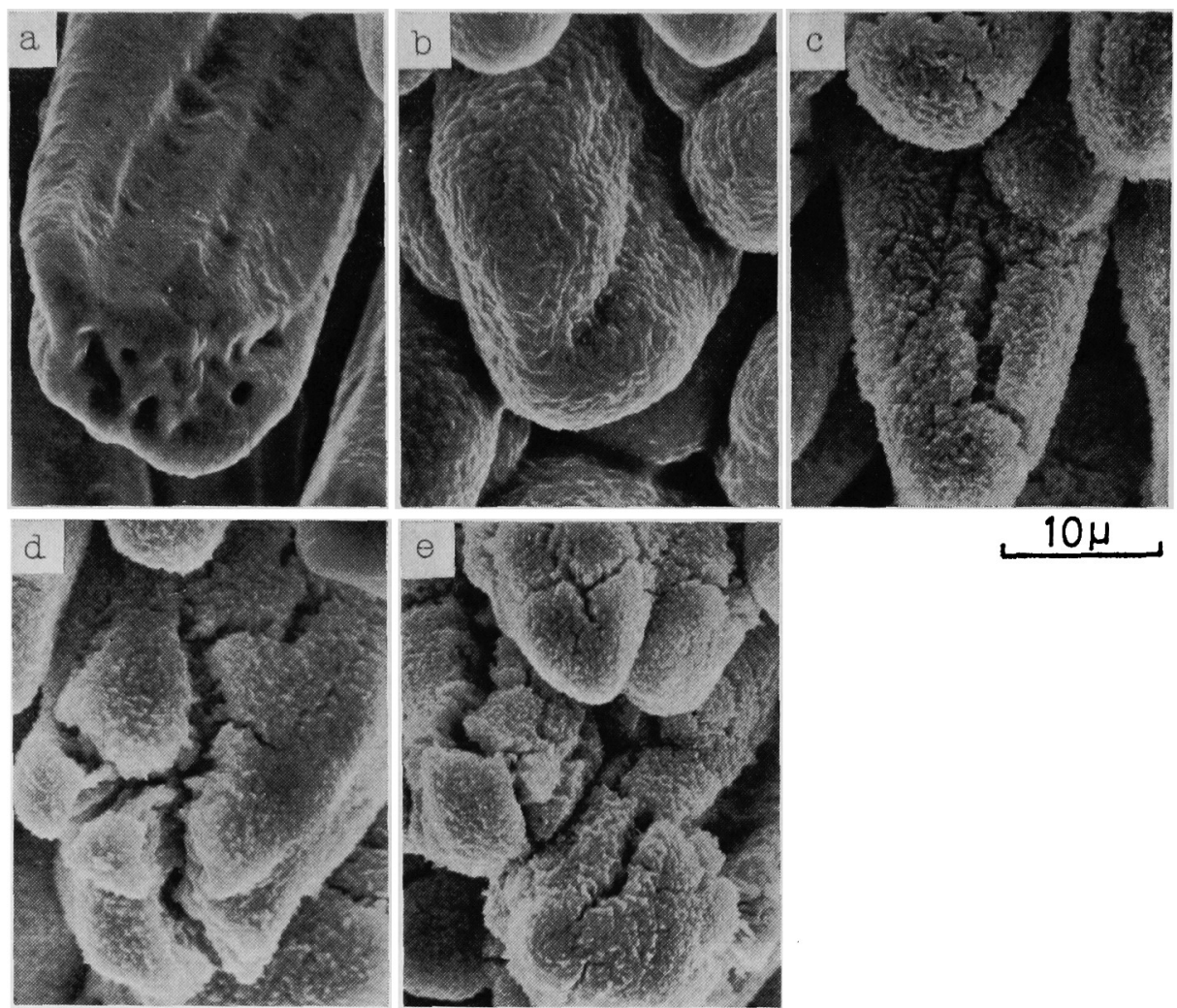

$10 \mu$

a : Before heating. b:5min. c : $10 \mathrm{~min}$. d : $30 \mathrm{~min}$. e : $1 \mathrm{~h}$. Tilting angle $30^{\circ}$

Photo. 4. Scanning electron micrographs of the boride $\mathrm{Fe}_{2} \mathrm{~B}$ which was heated in air for various times at $700^{\circ} \mathrm{C}$.

に示すように実験的记は重量增加一封間線図は，ほ汸放 物線則に従うと考元られる. 放物線則は次式で示され る.

$$
x=k \cdot t^{1 / 2}
$$

ここで $x$ : 重量増加, $k$ : 酸化速度定数, $t$ : 加熱時 間である.また酸化速度定数 $k$ と温度 $T$ との関係沈次の アレニウスの式10)によつて示される.

$$
k=A \exp \left(-\frac{Q}{R T}\right)
$$

ここで $A$ : 比例定数, $Q$ : 活性化エネルギー, $R:$ 気 体定数, $T$ : 絶体温度である.

したがつて，両辺を対数で示すと $\log k$ 上 $1 / T$ の傾 きがーQ/4.575 に等しい.Fig. 4 に $\log k$ Ł $1 / T$ との

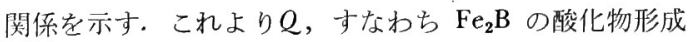
の見かけの活性化エネルギーとして，25.1 kcal $/ \mathrm{mol}$ t 得た。

\section{$3.4 \mathrm{X}$ 線回折}

Fig. 5 は $950^{\circ} \mathrm{C}, 3 \mathrm{~h}$ 号化処理後, $800^{\circ} \mathrm{C}, 8 \mathrm{~h}$ 大 気加熱, 後空冷した場合, はく離した酸化物スケール：

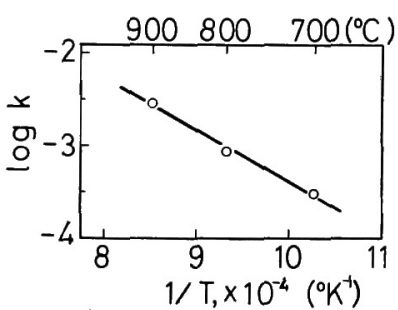

Fig. 4. Relationship between the $\log k$ and the $1 / T$.

a，および素地部：bのX線回析図を示す.スケールは 乳鉢にて粉砕し回折用試料とした。はく離したスケール の回折結果は、いくつかの不明線が認められる. しかし ほう化物 $\mathrm{Fe}_{2} \mathrm{~B}$ 㹥すべて, $\mathrm{Fe}$ 系, $\mathrm{Fe}-\mathrm{B}$ 系酸化物に变 化した。不明線は Fe, Fe-B あるいはB系の酸化物と考 兄られる。一方, 素地部からは $\mathrm{Fe}_{2} \mathrm{~B}(002), \alpha-\mathrm{Fe}(110)$ が強く現われ，ほかには $\alpha-\mathrm{Fe}_{2} \mathrm{O}_{3}, \mathrm{Fe}_{3} \mathrm{O}_{4}, \mathrm{Fe}-\mathrm{B}$ 系酸 化物が認められた。

Fig. 6 は高温酸化したほう化処理鋼の断面図を示す. 


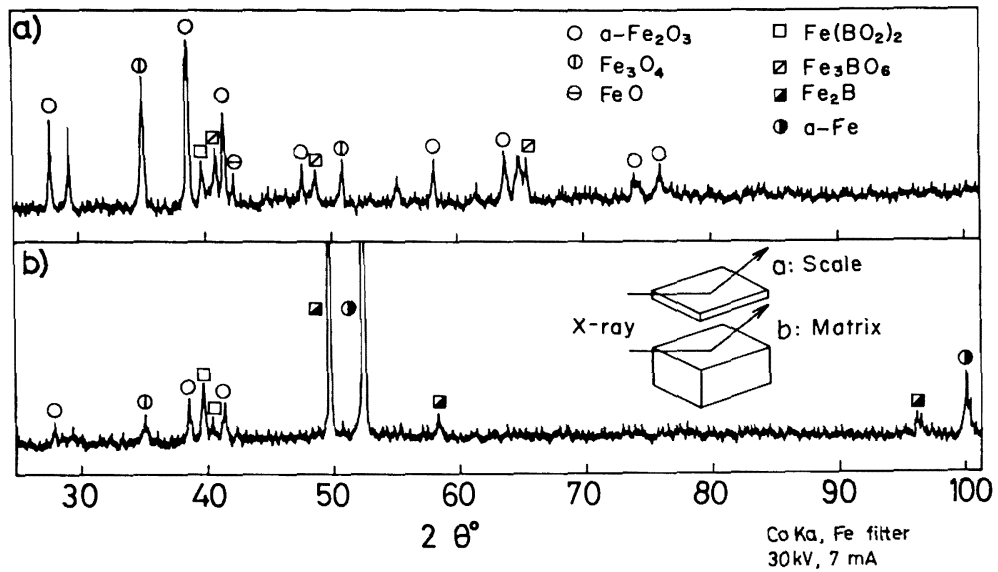

a : Oxide scale b: Matrix

Fig. 5. X-ray diffraction patterns of the exfoliated oxide scale and matrix which were heated in air at $800^{\circ} \mathrm{C}$, for $8 \mathrm{~h}$ after being borided at $950^{\circ} \mathrm{C}$ for $3 \mathrm{~h}$.

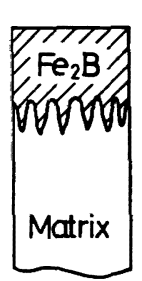

(a)

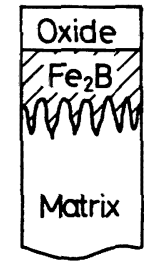

(b)

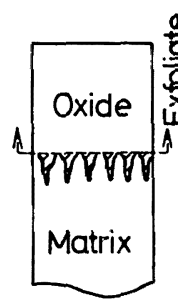

(c)

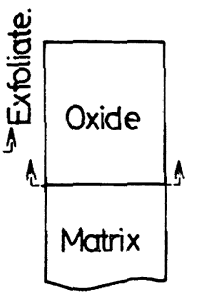

(d)

a : Before oxidizing $b$ : Oxidized a little. c, d : Oxidized largely.

Fig. 6. Cross-sectional patterns of the borided steel which was oxidized at high temperature.

$\mathrm{a}$ は末加熱, $\mathrm{b}$ は酸化の初期で $\mathrm{Fe}_{2} \mathrm{~B}$ 表面が分解, 一部 酸化物に変化している. c は酸化がさらに進み，ついに はdのようにすべて酸化物になる. Fig. 5, bの結果は, Fig. 6，cの点線の部分ではく離したことを示してい る.高温加熱したほう化処理鋼に急激な温度変化を与え た場合，スケールと素地との熱膨張係数の差などにより Fig. 6 の，dの素地部とスケールの界面からはく離寸 ると考えられる。

Table 2 は, 種々の温度, 時間で大気中加熱したほう 化処理鋼表面の $\mathrm{X}$ 線回折結果在示す. $950^{\circ} \mathrm{C}, 3 \mathrm{~h}$ 処理

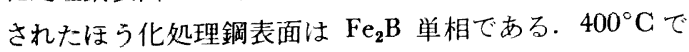
1，3，8h および $500^{\circ} \mathrm{C}, 1 \mathrm{~h}$ 加熱の場合，ほう化層表 面は未加熱のものと同様で $\mathrm{Fe}_{2} \mathrm{~B}$ のみであつた. $400^{\circ} \mathrm{C}$ $16 \mathrm{~h}$ および $500^{\circ} \mathrm{C}, 3 \mathrm{~h}$ 以上では $\mathrm{Fe}_{2} \mathrm{~B}$ と $\alpha-\mathrm{Fe}$ が認 められた. 温度, 加熱時間が増加するにしたがい $\alpha-\mathrm{Fe}$ の強度が增加している. これは $\mathrm{Fe}_{2} \mathrm{~B}$ より $\alpha$ - $\mathrm{Fe}$ が析出

Table 2. X-ray diffraction result of the borided steel surface which was heated in air at various temperatures and times.

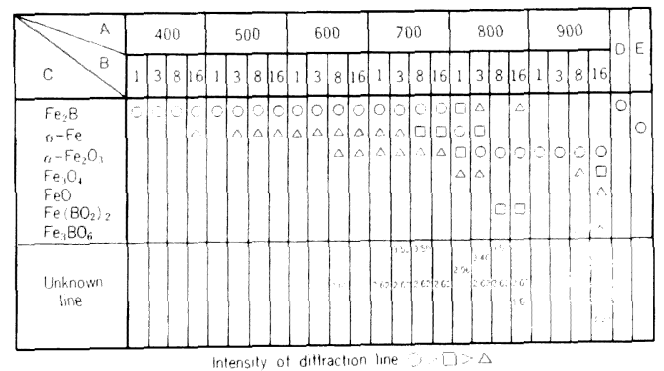

A: Heated temperature, ${ }^{\circ} \mathrm{C} . \mathrm{B}:$ Heated time, h. C: Detected composition. D: Borided specimen. E : Unborided specimen.

したことを示す． $600^{\circ} \mathrm{C} ， 8 \mathrm{~h}$ になると酸化がさらに進 み $\alpha-\mathrm{Fe}_{2} \mathrm{O}_{3}$ が認められ加熱時間が增すにしたがつて $\mathrm{X}$ 線強度が増加している. また $d=2.62 \AA$ に不明線が認 められ，700 $\mathrm{C}$ 加熱になる上，長時間になるほど強度が 增加している。これは明らかに酸化物上考えられるが， $\mathrm{Fe}$ 系, $\mathrm{Fe}-\mathrm{B}$ 系あるいはB采か定かでない，また 3.50 Aにも不明線が認められた。

$700^{\circ} \mathrm{C}$ 加熱までは表面は $\mathrm{Fe}_{2} \mathrm{~B}$ が主体である.しかし $800^{\circ} \mathrm{C}$ 加熱になると酸化は急激に進み表面組成が大き く変化している. $1 \mathrm{~h}$ 加熱では $\alpha-\mathrm{Fe}$ が，それ以上の封 間, 温度では $\alpha-\mathrm{Fe}_{2} \mathrm{O}_{3}$ が主体になる.しかしこれは $\mathrm{X}$ 線が侵入する表面部のかきられた範囲の分析であり，酸 化物スケール全体では種々の酸化物から成つている。事 実，Fig. 5，aに示したように，はく離したスケールを 乳鉢にて粉砕すると $\alpha-\mathrm{Fe}_{2} \mathrm{O}_{3}$ が主体ではあるが表面分 
Table 3. Comparison between the linear thermal expansion coefficient of the boride and oxide or the boride and matrix.

\begin{tabular}{ccccc}
\hline Elements & $\begin{array}{l}\text { Linear thermal expansion } \\
\text { coefficient. } \times 10^{-6} \cdot{ }^{\circ} \mathrm{C}^{-1}\end{array}$ & $\begin{array}{c}\text { Temp. range } \\
{ }^{\circ} \mathrm{C}\end{array}$ & $A / B$ & $C / D$ \\
\hline $\mathrm{Fe}_{2} \mathrm{~B}$ & $7.8511)$ & $200 \sim 600$ & 0.53 & 1.95 \\
$\mathrm{Fe}^{\mathrm{Fe}}$ & $15.3^{12)}$ & $0 \sim 900$ & 1.03 & - \\
\hline
\end{tabular}

$A / B$ : Thermal expansion coefficient of the elements/Thermal expansion coefficient of the $\mathrm{Fe}_{2} \mathrm{O}_{3}$.

$C / D$ : Thermal expansion coefficient of the $\mathrm{Fe}$ /Thermal expansion coefficient of the boride.

析では認められなかつた種々の組成が娭出された。

$900^{\circ} \mathrm{C} ， 1 ， 3 \mathrm{~h}$ 加熱になると表面部は $\alpha-\mathrm{Fe}_{2} \mathrm{O}_{3}$ の みで $8,16 \mathrm{~h}$ 加熱になると他の $\mathrm{Fe}$ 系， $\mathrm{Fe}-\mathrm{B}$ 系酸化物 が認められた. $16 \mathrm{~h}$ 加熱では最表面の $\mathrm{X}$ 線回折, 前述 Photo. 2 での断面観察でも $\mathrm{Fe}_{2} \mathrm{~B}$ は認められない. この ように $900^{\circ} \mathrm{C}$ の長時間加熱では $\mathrm{Fe}_{2} \mathrm{~B}$ はすべて酸化物 に変化した、ほう化処理鋼は表面が高硬度であり耐摩耗 性である，といわれているがこのようにほう化物が消失 し，すべて酸化物に变化すると耐摩耗性はもはや期待で きないと考える。

\section{4. 考察}

Table 3 はほう化物と酸化物，およびほう化物と素地 の熱膨張係数の比較を示す. 本研究によれば，高温酸化 を受けたほう化処理鋼表面は Fig. 6，bに示したよう に素地， $\mathrm{Fe}_{2} \mathrm{~B}$ ，酸化物が 3 層状を成している。酸化物は $\mathrm{Fe}$ 系， $\mathrm{Fe}-\mathrm{B}$ 系など実際には複雑な層を形成しているが $800^{\circ} \mathrm{C}, 900^{\circ} \mathrm{C}$ の高温では最表面は $\alpha-\mathrm{Fe}_{2} \mathrm{O}_{3}$ が主体で ある. $\mathrm{Fe}$ と $\mathrm{Fe}_{2} \mathrm{O}_{3}$ の熱膨張係数の比は 1.03 で比較的 1 に近い值である. $\mathrm{Fe}_{2} \mathrm{~B}$ の熱膨張係数は $7.85 \times 10^{-6}$ で $\mathrm{Fe}$ および $\mathrm{Fe}_{2} \mathrm{O}_{3}$ のそれに比較して小さい。 また $\mathrm{C} / \mathrm{D}$ が1，あるいは1よりわずかに低い值の場合，素地とほ う化物との密着性が最も良好である. $\mathrm{Fe}_{\mathbf{2}} \mathrm{B}$ の場合, 1.95 で素地の方が膨張が大きく，熱膨張係数の差のみを考兄 ると $\mathrm{Fe}-\mathrm{Fe}_{2} \mathrm{O}_{3}$ 界面より $\mathrm{Fe}-\mathrm{Fe}_{2} \mathrm{~B}$ 界面の方がはく離し やすいと考える.

本研究では，はく離したスケール，および素地のX線 回折結果より $\mathrm{Fe}_{2} \mathrm{~B}$ がすべて酸化物に変化 (Fig. 6, a ) した場合は勿諭， $\mathrm{Fe}_{2} \mathrm{~B}$ が一部残つている状態（Fig. 6， c）でも，酸化物との界面ではく離が認められた。

はく離の明確な挙動は， $\mathrm{Fe}_{2} \mathrm{~B}$ に生ずる酸化物の組成 が多種でその物性を十分把握できないこと，およびくい 状ほう化物が素地にくい込んでいるためより複雑なこと などにより正確な結諭は得がたい。

ほう化物 $\mathrm{Fe}_{2} \mathrm{~B}$ の酸化挙動を把握することは, ほう化 処理鋼の酸化挙動を論ずるうえで重要である. Photo. 4
より加熱したほう化物が微細なくい状を呈し表面積が大 きく割れやすい環境にあつたのはいなめないが，このよ うな激しい割れはほう化物表面上に生じた化合物との熱 膨張係数の差が主原因とは考えにくく，やはり $\mathrm{Fe}_{2} \mathrm{~B}$ 自 身が熱に耐えられず割れ，崩壊したと考える．これはく い状ほう化物 $\mathrm{Fe}_{2} \mathrm{~B}$ 自身は， $700^{\circ} \mathrm{C}$ で容易に割れ，崩壊 が生じることを示す. しかし一方，ほう化処理鋼を 700 ${ }^{\circ} \mathrm{C}$ で1 h 加熱した場合, 表面は Photo. 4, e に示した ような激しい割れ，あるいは崩壊は認められなかつた。 この理由としては，前述したように，ほう化処理鋼表面 とくい状ほう化物とでは，酸化雲囲気に接する表面積が 異なるこさ，およびくい状ほう化物が素地にくい込んで いるためほう化物にき裂が生じても崩壊, はく離が生じ にくいこと, が考えられる.

ほう化処理鋼の加熱では, Photo. 1, Fig. 3 に示した ように $16 \mathrm{~h}$ 加熱でも酸化物スケールの厚さが $28 \mu$ 程 度, また重量增加も $8 \mathrm{~h}$ 加熱の場合, 未処理鋼の約 $1 / 7$ である結果より $\mathrm{Fe}_{2} \mathrm{~B}$ が母材の酸化速度を著しく遅らせ ている事実は明らかである。この結果は， $\mathrm{Fe}_{2} \mathrm{~B}$ あるい は $\mathrm{Fe}_{2} \mathrm{~B}$ が分解し, 生成した酸化物が素地の保護被膜と して作用していることを示す. しかし一方，ほう化処理 鋼は $700^{\circ} \mathrm{C}$ 加熱でも確実に酸化が進行するが，その速 度は未処理鋼に比べ著しく小さいといえる。

重量增加測定については，酸化時間が 8 h 以下につい て行なつたが本研究の範囲では, 長時間酸化後の耐酸化 性被膜の状況が不明であり, 長時間酸化についても检討 する必要を感じる.

$\mathrm{X}$ 線回折結果からは，ほう化処理鋼は $700^{\circ} \mathrm{C}$ 加熱ま では表面は $\mathrm{Fe}_{2} \mathrm{~B}$ が主体である、 $\mathrm{Fe}_{2} \mathrm{~B}$ が存在する間は $\mathrm{Fe}_{2} \mathrm{~B}$ が保護被膜として作用するため良好であるが 800 ${ }^{\circ} \mathrm{C}$ 加熱になると表面組成が大きく変化し $900^{\circ} \mathrm{C}$ では, $\alpha-\mathrm{Fe}_{2} \mathrm{O}_{3}$ が主体になる。 このように酸化物が主体になる と酸化物が安定なものでないかぎり金属の保護性は期待 できない， $\mathrm{Fe}_{2} \mathrm{~B}$ が酸化し $\mathrm{Fe}$ と $\mathrm{B}_{2} \mathrm{O}_{3}$ に分解したと仮 定すると $\mathrm{B}_{2} \mathrm{O}_{3}$ はガラス質で $1000^{\circ} \mathrm{C}$ 程度までは保護的 である，といわれ $\mathrm{B}_{2} \mathrm{O}_{3}$ が連続被膜を形成する範囲では 
一応保護的と考える. しかし本研究の範囲では $\mathrm{B}_{2} \mathrm{O}_{3}$ の 正確な確認はできなかつたが高温加熱することにより試 料直下のルツボ底部に透明なガラス質の付着物が認めら れた.これは加熱によりほう化処理鋼表面から $\mathrm{B}_{2} \mathrm{O}_{3}$ が 溶出したと推察される.

以上を総括すると，ほう化処理鋼を加熱した場合 $\mathrm{Fe}_{2} \mathrm{~B}$ が存在する範囲では未処理鋼に比べ著しく耐酸化性であ る. また酸化により $\mathrm{Fe}_{2} \mathrm{~B}$ が消失しても酎酸化性被膜 $\mathrm{B}_{2} \mathrm{O}_{3}$ が存在し, 連続被膜を形成する範囲で注, 耐酸化 性は期待できると考える.しかし本研究では，ガラス質 の付着物が生成したが溶出してしまい耐酸化性には寄与 しなかつたと推察される.

重量増加測定では $800^{\circ} \mathrm{C}$ 加熱の場合, 著しく酎酸化 性である.しかしこれは $\mathrm{Fe}_{2} \mathrm{~B}$ が存在する範罒の測定で あり，X線回折結果より $800^{\circ} \mathrm{C}$ 以上では $\mathrm{Fe}_{2} \mathrm{~B}$ が急激 に酸化される結果, $800^{\circ} \mathrm{C}$ 以上では長時間加熱に対して 耐酸化性はあまり期待できないこ考える.

本研究では $700^{\circ} \mathrm{C} \sim 900^{\circ} \mathrm{C}$ の範囲で汪う化物 $\mathrm{Fe}_{2} \mathrm{~B}$ の酸化物形成の見かけの活性化エネルギーは $25.1 \mathrm{kcal} /$ $\mathrm{mol}$ を得た. Fe 中への酸素の拡散の活性化エネルギー は $\alpha$ 相（実験温度範囲：700 ${ }^{\circ} \mathrm{C} \sim 900^{\circ} \mathrm{C}$ ） の場合 10.1 $\mathrm{kcal} / \mathrm{mol}^{13)}$ で 25.1 より低い值を示す.これは実験方 法が同一ではないがほう化処理することにより酸化の反 応速度が小さくなりほう化物が金属の保護被膜として作 用していることを示す。

\section{5. 結言}

ほう化処理鋼，およびほう化物を種々の温度，時間， 大気中にて加熱し高温酸化挙動を検討した結果，次のよ うな結論を得た。

1) ほう化処理鋼を大気中にて加熱した場合, $\mathrm{Fe}_{2} \mathrm{~B}$ が 十分に存在する $700^{\circ} \mathrm{C}$ 程度までは耐酸化性は期待でき る.また $800^{\circ} \mathrm{C}$ 以上では $\mathrm{Fe}_{2} \mathrm{~B}$ が急激に酸化される結 果, 長時間加熱に対しては耐酸化性はあまり期待できな いと考える.

2 ）抽出したくい状ほう化物 $\mathrm{Fe}_{\mathbf{2}} \mathrm{B}$ の微片は比較的熱
に弱く $700^{\circ} \mathrm{C}, 1 \mathrm{~h}$ 大気中加熱により激しく酸化し，崩 壊も認められた。

3 ) 高温加熱したほう化処理鋼表面が急激な温度変化 などではく催する場合，ほう化物がすべて酸化物に変化 した場合はもちろん，注う化物が存在寸る場合も酸化物 スケールと素地あるいはほう化物との界面からはく唡与 ると考えられる。

4 ）注う化処理鋼を高温酸化させることによりほう化 物 $\mathrm{Fe}_{2} \mathrm{~B}$ 表面はおおよそ次のように変化した。より高温 長時間加熱になるほど右に変化する。

$$
\begin{aligned}
& \mathrm{Fe}_{2} \mathrm{~B} \rightarrow \underset{\alpha-\mathrm{Fe}}{\mathrm{Fe}_{2} \mathrm{~B}} \rightarrow \underset{\alpha-\mathrm{Fe}}{\mathrm{Fe}_{2} \mathrm{~B}} \rightarrow \underset{\mathrm{Fe}-\mathrm{B}-\text { Oxide }}{\mathrm{Fe}-\text { Oxide }} \\
& \text { Fe-Oxide } \\
& \text { F-B-Oxide }
\end{aligned}
$$

5 ) 大気中 $700^{\circ} \mathrm{C} \sim 900^{\circ} \mathrm{C}$ の範围でほう化物 $\mathrm{Fe}_{2} \mathrm{~B}$ の 酸化物形成の見かけの活性化エネルギー, $25.1 \mathrm{kcal} / \mathrm{mol}$ 龙得た。

\section{文献}

1)エリ・エス・リヤホヴィッチ，他：食属の保護被 倠，(1968)，p. 127，日ソ通信社訳

2 ) ヴェ・ヘ・グルホフ: 鉄と鋼のボロガイジング, (1970)，p. 108，日ソ通信社訳

3 ) 藤井京子, 片桐敏夫, 荒木 峻: 金属学会誌, 38 (1974), p. 698

4 ) 鳥井強三, 朝倉 哄, 仲川政宏, 小松 登, 新井 透，遠藤淳二：鉄と鋼，59(1973), p. 1287

5 ) 啮谷佳男：材料，25(1976), p. 336

6 ）渉谷佳男：材料，26(1977), p. 120

7 ) 车田明徳，戸田堯三，島軒治弥：金属学会誌，31 (1967)， p. 296

8 ) 高本信次郎, 片桐敏夫, 藤井京子, 片桐義僬：金 属学会婄31 (1967), p. 338

9 ) 鈴木, 川端, 須永: 学振 123 委報告 15(1974), p. 51

10) $R$. W. Gurry and $L$. S. Darken: Physical Ghemistry of Metals, (1953), p. 466

11) $M$. Deger, $M$. Riehle, and $W$. Schatt: Neue Hütte, 17(1972), p. 341

12) R. F. Tylecote: JISI, 196(1960), p. 135

13) $W \cdot$ ヒュームロザリー：鉄鋼物性工学入門, (1968)， p. 289, 平野訳 